\title{
A Study on Corporate Earning Retention in India
}

\author{
DR. P. PARAMASHIVAIAH', \\ DR. ARAVIND S. ${ }^{2} \&$ \\ Dr. T. ASWATH NARAYANA ${ }^{3}$
}

The role of saving in economic development has been recognized well by many Economists and empirical studies. Most of the industrializing economies in the world witnessed higher saving rates as compared to others. The countries achieving the highest saving rate between $30 \%$ and $50 \%$ of Gross Domestic Product are able to achieve higher economic and social developments. High saving rate was considered to be one of the important factors leading to fast economic development. The financial liberalization in the form of deregulating the interest rates, reducing the credit restrictions and opening-up of the financial market for foreign participants resulted in mobilizing saving for productive purposes. Liberalization with enhanced efficiency of the financial systems and proper channeling of saved resources in to productive uses would provide for the increase in income. The increased income resulting in higher consumption would lead to increased production and profitability. As the profitability is an important factor influencing corporate saving, the capacity of corporate entities to save depends on profit earning ability.

\section{Introduction}

The role of saving in economic development has been recognized well by many Economists and empirical studies. Most of the industrializing economies in the world witnessed higher saving rates as compared to others. The countries achieving the highest saving rate between $30 \%$ and $50 \%$ of Gross Domestic Product are able to achieve higher economic and social developments. High saving rate was considered to be one of the important factors leading to fast economic development. The financial liberalization in the form of deregulating the interest rates, reducing the credit restrictions and opening-up of the financial market for foreign participants resulted in mobilizing saving for productive purposes. Liberalization with enhanced efficiency of the financial systems and proper channeling of saved resources in to productive uses would provide for the increase in income. The increased income resulting in higher consumption would lead to increased production and profitability. As the profitability is an important factor influencing corporate saving, the capacity of corporate entities to save depends on profit earning ability.

1 Professor, Government RC College of Commerce, Palace Road, BANGALORE, Karnataka, INDIA.

2 Professor, Dept. of Management, Arba Minch University, Arba Minch, P.O.Box.No.21, ETHIOPIA.

3 Faculty Member, Government RC College of Commerce, Palace Road, BANGALORE, Karnataka, INDIA. 
GDP growth rate in agricultural sector in India is very small. For accelerating GDP growth it becomes an essential part to focus on corporate expansion for manufacturing the products and rendering services. Corporate expansion is possible only their is gradual and substantial corporate investment in productive assets. This can be done by increasing the equity, debt, and retention and attracting foreign investments. The equity and foreign investments are being influenced by macro factors. To some extent the debt and retentions are within the control of firms. For increasing the leverage (increasing the debt content) when the asset expansion is considered, it becomes obligatory for firms to maintain the required level of own funds. When the equity is inadequate and further issue of equity is constraint by market factors, the option available would be to retain the profit for expansion.

The growth of the private manufacturing sector depends on profitability. Competition enforced the companies to work with a thin profit margin. Such a working environment has induced restructuring within industry. One of the important means of restructuring is acquisitions and mergers. Constrained with the reduction in profit with the option to consolidate for survival creates a situation for funds mobilization internally and externally. In a restricted and saturated external financing situation, a firm has to solely depend on its cash generation for it profitable expansion program. The decision relating to the retention of earnings for financing the capital stock or current assets depends on the cost of borrowing, the availability of and accessibility to funds in the markets. For a firm having substantial earnings, the availability is not a constraint but cost will be an important factor for consideration. The prevailing interest rate, expectation of investors and cost of issue determine the cost of external borrowing and funds. For medium and small firms the accession to stock market and cost of issue would be impediments as compared to the easily available retained earnings. Sharp increase in debt content will create a future interest burden on earnings and external financing through equity is constrained with market conditions and company position in the market. Keeping these in view the company's dependability on internal cash generation and retention has become one of the important options for survival. While scanning through the proportion of internal finance of firms in United States of America and United Kingdom, we find in USA the internal funds range from $55 \%$ to $80 \%$ of total investment and in UK it ranges from $25 \%$ to $67 \%$. When we compare the internal finance of firms from (High Performing South East Asian) HPSEA Countries we find Indian firms' internal finance is comparatively lower. The proportion of internal finance of Korean firms has increased from $27 \%$ of total finance to $50 \%$ during 1999 and 2000. Indian firms dependability on bank borrowing is comparatively higher than other industrially developed and HPSEA countries. Tax benefits of debt fund, optimum leverage, optimum capital structure, business risk, earning ability, interest burden on earnings, reinvestment opportunities, dividend policy, liquidity position, lender stipulation, debt market, investor expectation, industry financial practice, investment demand, cash flow etc have their impact on the decision relating to retain the profit for increasing internal finance portion of the total investment.

In the macro economic environment any growing economy in the world witnessed a high rate of capital formation and investment. Adequate Capital formation from balanced savings protects the country from any shocks from economy and capital markets. Similarly in the micro firm level the retained earnings (Corporate saving) of a firm protects the organization from the risks arising out of external factors like interest hike, credit squeeze, change in the lending norms of financial institutions etc. This provides adequate impetus for corporate expansion. For self-sufficiency, capital formation, enhanced borrowing capacity, maintaining optimum capital structure, maximizing shareholder wealth and enhancing the credit worthiness of the organization, management has to precisely design the pay out policy, retention and plough back of earnings. 
From the macro point of view corporate saving is considered to be an important component in total national savings of economically developed and high growth rate countries. Where as in India the portion of corporate saving is around $4 \%$ of GDP and the total national saving is $27 \%$ of GDP. This creates a need to increase corporate savings to ensure a sectoral balance in the supply of funds in the economy. When we compare the corporate saving and the fund requirement for the corporate sector, the corporate saving is found to be very low and the corporate sector draws funds from the national saving. The changing financial environment demands greater saving effort for expansion and survival. It has been argued by the industrialist that the post tax profitability is inadequate to plough back after satisfying the investors by paying dividend, the depreciation allowance given is not adequate to replace the used assets in the inflationary condition and the inactive primary capital market imposes the condition to borrow for expansion. The borrowing power of corporate entity is also constrained by capital structure, leverage, servicing ability, availability of own funds, management quality, business risk and credit policy and stipulations of the lending institutions. Thus the corporate entities have to operate effectively with the financial market constraints. In such a situation the corporate saving has both the macro level and micro level significance. The micro level self-reliant firms with stable growth in the country will facilitate for macro economic growth.

The study therefore aims to analyze the trend of saving proportions by manufacturing public limited companies in India for the period of 15 years from 1990-91 to 2003-2004.

\section{Factors affecting Corporate Earning Retention:}

The term corporate saving refers to the retained profits after distributing dividends. The capacity of a company to save depends on the ability of it to earn profit after deducting tax. The ability to save also depends on the ability earn cash profit. The cash profit after tax provides liquidity to finance the dividends and savings. The liquidity position also determines the working capital fluctuations in an organization. The need for increased working capital plays a role in saving decision. Higher the demand for the expansion of working capital, higher would be the requirement of margin money to finance the incremental working capital. This situation would have an impact on profit retention and distribution decisions. Lower liquidity and higher demand for incremental working capital would imply for stringent dividend payments and higher retention in the business.

The depreciation allowance provided under tax aspect provides the corporate entity to minimize the effective rate of tax on profit. Because of this the effective rate of tax would be considerably lesser than the nominal rate of tax. High depreciation allowance would attract for further investment in physical assets attracting higher rate of depreciation. This in turn induces the investment demand when there is attractive return on investment.

In a stock market where capital gain is negative or very low, the corporate entities would try to maximize the shareholders wealth by maximizing its Earning Per Share (EPS) and dividend payments. In such a situation there would be a trade of between the dividend payment and saving decisions. Both the dividend and saving decisions are likely to influence one another. When there are entry restrictions like high floatation costs, high cost of equity, unfavorable condition for fresh issue of shares, the companies have to depend on internal finance and borrowing. The borrowing also demand for margin money, which in turn creates demand for internal financing.

Most of the profitable companies would try to maintain regularity and stability in dividend rates and payments. Those companies maintaining stability and regularity in dividend payments will have to save based on the profitability position. The saving proportion would closely associate with the profit after tax if stable dividend policy is adopted. In other words there would be higher positive correlation between PATs and Savings. The impact of PAT on saving would be better explained than the impact of PAT on dividend payment. However there will be a stable relationship between the profit of a company, its retention and dividend distributions. 
The life cycle stages of the company and industry also influence the saving and dividend decisions. Aged and matured companies follow a liberal dividend policy where as the growing and new companies would follow higher proportion of saving policy. The new and growing companies try to build up retained earnings in order to meet the stipulations of lending institutions and to face the challenges of business risks likely to arise in the initial and growing stages. The nature of the industry, business activities and the profit earning ability of the company would also influence the saving and distribution proportions of earnings. The business having high volatility in earnings would try to avoid higher proportion of dividend distribution but would try to save higher proportion to maintain a constant level of dividend payments. Thus the fluctuating earnings induce the lower payout ratio and higher saving ratio. The rapidly growing companies will have to depend on long term funds. For mobilizing long term loans, adequate internal source of fund is required. While borrowing, the management has to consider the capital structure, cost of capital, service ability and tax aspect. For growing companies high leverage is not financially advisable and hence optimal capital structure with the optimal mix of internal funds and external borrowing would provide adequate financial protection. For this the growing companies have to retain major portion of their earnings and whereas the companies with no growth rate or low growth opportunities would prefer to maintain low saving ratio. Thus the growth rate of the company also influences the retention decisions.

\section{Methodology and Sample}

Population for the Study -

Manufacturing Public Limited Companies in India.

\section{Sample Selection:}

As the retention (saving) capacity of firm depends on the earning ability, the companies having positive Profit After Tax (PAT>0) were filtered from Prowess Data base. Year wise filtering was done.
Second stage filtering was done to eliminate the service sector and public sector corporate entities. From the second stage filtering the researcher got the year wise list of public limited manufacturing companies having earning ability.

From the year wise detail, third filtering was done to identify the companies having Profit after tax for 10, 11, $12,13,14$ and 15 years during the period from 1990-91 to 2003-04.

Retention of profit is possible only when there is profit after tax. A part of profit is distributed as dividend and another part is retained in business as saving. Hence the study is limited to the companies having profit after tax. In order to differentiate the saving behavior and proportion of saving by companies, the sample has been divided in to two groups.

Group1: Companies having positive PAT (Profit After Tax) continuously for the period of 15 years. These companies are classified as the "companies with consistent earning ability" (CEA companies). Total number of companies under this group is 113 in numbers from different industries.

Group 2:Companies having positive PAT for not less than 10 years during the period of 15 years of the study. Under this group we get 896 companies. These companies are known as "All companies" (This group includes the group 1 companies also). In this group we have further classification of 179 companies having positive PAT only for 10 years from the period of 15 years. These companies are known as "Companies with Inconsistent Earning Ability" (IEA Companies)

\section{Objectives:}

1. To Study the Corporate retention proportion (Saving Ratio) in corporate earnings in India.

2.To study and analyze the mean values of Saving ratio, Dividend Percentage, Interest burden \& Tax burden of CEA and All companies To Identify the Variable (s) that influences the corporate retention in these companies. 
3. To identify industry-wise differences in the impact of these variables on earning retention.

\section{Methodology:}

1. To study the Retention Ratio, Year wise, industry wise and company wise classification (CEA, IEA and ALL) analysis has been done be using mean values and standard deviations.

2. The mean value of saving Ratio has been analyzed by comparing Dividend percentage, interest burden, tax burden and liquidity position.

3. To identify the variables influencing the retained earning, Stepwise regression method has been used. The following variables are considered in the study.
A. Total Dividend Paid.
B. Depreciation.
C. Tax.
D. Interest.
E. Working Capital.

\section{Concepts Used in the Study:}

1.Saving Ratio = Retained earning/Profit After Tax.

2. Interest Burden $=$ Interest $/$ Profit Before Interest and Tax

3.Tax Burden = Corporate income tax/Profit before tax

\section{Analysis and Findings:}

1. There is overall declining trend in saving ratio of Indian Companies during the period of fifteen years. (Table 1)

2. Manufacturing companies also reflected the same trend during the period. (Table1)

3. The overall saving ratio of Indian corporate entity is better than the saving ratio of manufacturing companies. This is because of higher saving ratio of service Industry in India.

4. CEA companies pay higher dividend than the IEA companies. The dividend consistency is better in CEA companies than IEA companies. (Table2)

5. CEA companies are using higher proportion of debt than IEA companies and hence they pay higher dividend. (Table 2)
6 The saving ratio of IEA companies is better than the saving ratio of CEA companies since the IEA companies pay lesser dividend. (Table 2)

7. The trend of CEA companies' saving ratio has been found in declining pattern and associated with increasing dividend percentage. The same trend has been observed in all companies saving and dividend distribution. We find significant negative association between saving ratio and dividend in CEA companies' results. (Tables 3 and 4 )

8. CEA companies in Automobile, chemical \& diversified industries pay lesser than the IEA \& other companies from these industries. This clearly indicates that the companies with inconsistent earning ability in these industries (automobile, chemical and diversified) earn more, pay more dividends than CEA companies. (Tables 5 and 6)

9. From Summary regression model (model considering 896 companies), we observe the following results. (Table 7)

a) In 12 industry wise multiple regression equations, tax has been found an important variable positively influencing retained earning in 11 industries. In diversified industry, tax negatively influences the retained earning.

b) Working capital has been found to be a dominating variable in 11 industries. In cement industry working capital has been excluded from the model indicating weak relationship between working capital \& retained earning in this industry

c) Depreciation has also been considered as an influencing variable of retained earning in 11 industries, but the influence is the mixture of positive and negative in nature.

d) Even though interest has been included as influencing variable in the summary model, we find this variable is missing in may industry wise regression equations. Hence we can conclude this variable is not so important in influencing the retained earning.

\section{Hypotheses and Conclusions:}

Five hypotheses were formulated in the study using five variables. They are:

Hypothesis 1: Earning Retention is negatively influenced by dividend payments. 
Hypothesis 2: Earning retention is positively influenced by the tax payments.

Hypothesis 3: Earning retention is negatively influenced by interest payments.

Hypothesis 4: Working capital positively influences the earning retention.

Hypothesis 5: Depreciation positively influences the earning retention.

Hypothesis 1: Earning Retention is negatively influenced by dividend payments.

All Companies: (896 companies)

This hypothesis has been proved at $1 \%$ significance level in the summary regression model. In industry wise analysis, automobile, machine manufacturers and software companies proved this hypothesis. Auto ancillary, cement, diversified, iron and steel and textile companies disproved this hypothesis.

\section{CEA Companies: (113 companies)}

The same hypothesis has been disproved in case of CEA companies. In CEA companies the positive influence of dividend on retention indicates the increasing earning ability is associated with the increased dividend and higher retention. In Industry wise analysis this hypothesis has been proved in software and Machine manufacturer industries.

Companies, which constantly increase the dividend payments with lower saving proportion, would result in negative influence of dividend on earning retentions.

Hypothesis 2: Earning retention is positively influenced by the tax payments.

This hypothesis has been formulated based on the following assumption.

High tax bracket companies would prefer to go for higher leverage to maximize the earning per share. For achieving the desired leverage, the companies have to borrow and while borrowing, adequate margin money (own funds) should be made available. Assuming that there is no increase in equity and preference capital, the only option for the company to raise own fund is from profit retention.
Hence they would try to retain the profits to achieve desired leverage. This situation would result in higher amount of retention in high tax paying companies. Alternatively, tax is positively associated with profit and profit is positively associated with saving when there is a constant dividend percentage of payment.

This hypothesis has excellently been proved in CEA and ALL companies. Except diversified Industry, all the industries either from CEA group or All group proved this hypothesis at $1 \%$ significance level.

\section{Hypothesis 3: Earning retention is negatively influenced} by interest payments:

The Summary models of CEA and ALL Companies support this hypothesis at $1 \%$ significance level. However companies from electrical, industrial products, Iron and steel and software industries disproved this hypothesis.

\section{Hypothesis 4: Working capital positively influences the} earning retention

This hypothesis is formulated based on the following assumptions.

Companies expanding their activities and operations have to expand their working capital limits for which they have to finance a portion of working capital expansion. For this they have to depend on internal source. For financing the part of working (margin money), the companies have to depend on earnings. Hence retained earning is one of the sources for providing margin money for working capital expansion.

This hypothesis has been proved to be true. We find the high positive impact of working capital on retained earnings in CEA and ALL companies.

However this has been disproved in cement industry. Cement companies retained earning is negatively influenced by working capital. This can be interpreted that retained earning would be a source for financing the erosion or decrease in working capital. However this has to be investigated and tested. 
Hypothesis 5: Depreciation positively influences the earning retention.

This hypothesis has been formulated based on the following assumption.

Companies enjoying higher depreciation rate would try to increase their cash earnings by further investing the earnings in business. Higher rate of depreciation would result in lower level of tax and higher cash profit. Hence the companies enjoying higher depreciation would try to retain and further invest in business. At $1 \%$ significance level, the CEA and ALL companies proved this statement.

Most of the industries proved this hypothesis except cement, iron and steel and industrial product manufacturers. These companies are capital-intensive units having lower earning ability with higher amount of depreciation. Due to lower ability of earning with constant dividend payment, the retained earnings are found to be lower as compared to the total depreciation. This situation resulted in negative influence of depreciation on earning retention. Further detailed investigation in to these industries would provide reliable results.

\section{Conclusion:}

1. Working capital is the dominating variable positively influencing the earning retention.

2. Tax has been found to be a vital and prevalent variable that influences the retention.

3. Depreciation is also playing its role in determining the retained earnings.

4. Interest and Dividends are negatively and negligibly influencing the earning retention.

\section{REFERENCES}

1. Alan J. Auerbach, "Issues in the Measurement and Determinants of Business Saving", National Bureau of Economic research Working paper No 1024.

2. Bhattacharya B. \& Jaydeep Mukherjee, "Determinants of Corporate saving in India", http://www.utiicum.com /jitendramahakud37.
3. Bhole L.M., "Financing of the Private Corporate Sector, Trends, Issues and Policies", Himalaya Publishing House, Millennium edition:2000, pp 15-34.

4. Bhole $L M$ "Retained Earnings, Dividends and Share Prices of Indian Joint-Stock Companies" Economic and Political Weekly, August 1980 page M-93 to M-100.

5. Chang-Tai Hsieh and Jonathan A. Parker, "Taxes and Growth in a Financially Underdeveloped Country: Evidence from the chilean Investment Boom" This Paper prepared for Macroeconomics and Growth Group at the World Bank and published on $25^{\text {th }}$ June 2002.

6. Christos N. Pitelis, "Corporate Retained Earnings and personal sector saving: a test of the life-cycle hypothesis of saving", Applied Economics, 1987- 19, P 907-913.

7. Davenport M, "Some Cross-Section Tests of the "Normal" earnings Hypothesis of Corporate Savings"

8. Dean Crawford, Diana R.Franz and Gerald J. Lobo, "The Retained Earnings Hypothesis: A Reexamination of the Evidence", Paper presented in the Accounting Workshop at Syracuse University on March 2001.

9. Deepak Chawla and Srinivasan G, "Impact of Dividend and Retention on Share Price - An Econometric Study" Decision Vol 14, No 3, July-September 1987 Page 137-140.

10. Feldstein. M.S. and Flemming. J.S., "Tax Policy, Corporate Saving and Investment Behaviour in Britain", Review of Economic Studies, 415-34

11. Henry G. Grabowski and Dennis C. Mueller, "LifeCycle effects on Corporate returns on Retentions", The review of Economics and statistics, Volume LII, No 4- Nov 1970-p 400-409.

12. Irwin Friend, and Marshal Pucket, "Dividends and Stock prices", American Economic Review Vol 54, No 5, Sept 1964- 656-681.

13. Jain P.K. and Surendra Yadav, "Dividend Policies and Practices: Empirical Evidences from India, Singapore and Thailand", South Asian Journal Management Volume 6, No 3 \& 4, July-Dec 1999, Page 54-63

14. James M. Poterba, "Tax policy and corporate saving", Brookings papers on Economic Activity, March 1987, p 455-515. 
15. John Lintner, "Distribution of incomes of Corporations among Dividends, Retained Earnings, and Taxes", American Economic Review", May 1956, 46, p 97-113.

16. Lynch P.J. and Witherell W.H., "The Carter Commission and the saving behaviour of Canadian Corporations", National Tax Journal, Vol. XXII.

17. Mahapatra R P "On the Saving Behaviour of General Engineering Industry" Aghigyan - Autumn 1996 page 41-57.

18. Mahapatra R.P. and Sahu P.K. "Corporate Saving Behaviour in India - An empirical Study" The Management Accountant, February 1994 page 21 -26.

19. Mohamed Abdul Salam and Umma Kulsum, "Saving Behaviour in India: An empirical study", The Indian Economic Journal, Volume 50 No 1. 76-80

20. Mohammed Nishat "Share prices, Dividend \& Share retained Earnings Behaviour in Pakistan Stock Market" The Indian Economic Journal Volume 40 No 2, page 56-65

21. Ramesh Bhat and Pandey I.M, "Dividend Decision: A Study of Manager's Perceptions", Decision, Vol 21, Nos 1 \& 2, Jan-June 1994, 67-83.

22. Rao G. N \& Sarma Y S R., "Dividend and Retained Earnings of Public and Private Limited Companies in Inidia, 1955-56 to 1965-66- An Econometric Analysis", Reserve Bank of India Bulletin, June 1971.

23. Robert C.Higgine, "The Corporate Dividend-Saving Decision", Journal of Financial and Quantitative Analysis, March 1972, p 1527-41.

24. Stephen G. Buell, CarBeidleman and Charles Moyer R, "On the Linkage between Corporate Saving \&Earnings Growth", The Journal of Financial Research, Vol IV No 2, Summer 1981, p 121-128.

25. Stephen J. Turnovsky, "The allocation of Corporate Profits between Dividends and Retained Earnings", The Review of Economic and Statistics, Volume 49, No 4, Nov $1967,583-589$.

\section{ANNEXURE}

Trend in Saving Ratio of Indian Companies

Table1

\begin{tabular}{|c|c|c|c|c|}
\hline Year & No. of & $\begin{array}{c}\text { Saving } \\
\text { Ratio }\end{array}$ & No. of & Saving Ratio \\
\hline & Companies & & Companies & \\
\hline & Manufacturing & & Manufacturing & \\
\hline & + & & & \\
\hline & Service & & & \\
\hline 1990 & & & & \\
\hline 1991 & 1184 & 0.835 & 522 & 0.736 \\
\hline 1992 & 1537 & 0.820 & 646 & 0.722 \\
\hline 1993 & 2195 & 0.810 & 737 & 0.708 \\
\hline 1994 & 2983 & 0.800 & 763 & 0.708 \\
\hline 1995 & 3888 & 0.795 & 844 & 0.718 \\
\hline 1996 & 4010 & 0.800 & 880 & 0.750 \\
\hline 1997 & 3495 & 0.787 & 878 & 0.760 \\
\hline 1998 & 3129 & 0.759 & 858 & 0.702 \\
\hline 1999 & 3088 & 0.729 & 808 & 0.700 \\
\hline 2000 & 3325 & 0.730 & 805 & 0.676 \\
\hline 2001 & 3213 & 0.718 & 749 & 0.700 \\
\hline 2002 & 3214 & 0.730 & 732 & 0.680 \\
\hline 2003 & 2951 & 0.693 & 723 & 0.640 \\
\hline 2004 & 2954 & 0.733 & 728 & 0.670 \\
\hline
\end{tabular}

Saving Ratio and Dividend \% of Sample Companies

Table - 2

\begin{tabular}{|c|c|c|c|c|}
\hline \multicolumn{2}{|c|}{ Mean values of CEA Companies (113) } & SD & Min & $\operatorname{Max}$ \\
\hline Saving Ratio & 0.68 & 0.11 & 0.27 & 0.89 \\
\hline Dividend \% & 40 & 22 & 0 & 121 \\
\hline Interest burden & 0.35 & 0.16 & 0.04 & 0.71 \\
\hline Tax burden & 0.41 & 0.21 & 0.01 & 1.00 \\
\hline Debt equity ratio & 0.88 & 0.46 & 0.06 & 2.27 \\
\hline $\begin{array}{l}\text { Return on Capital } \\
\text { employed }\end{array}$ & 26.91 & 9.05 & 12.88 & 55.20 \\
\hline & $\begin{array}{c}\text { IEA } \\
\text { COMPANE } \\
S(179)\end{array}$ & & & \\
\hline Saving Ratio & 0.77 & 0.15 & 0.25 & 1 \\
\hline Dividend \% & 14.38 & 19.70 & 0 & 220 \\
\hline Interest burden & 0.45 & 0.19 & 0.01 & 0.86 \\
\hline Tax burden & 0.31 & 0.33 & 0 & 2.54 \\
\hline Debt equity ratio & 0.55 & 8.14 & -106.7 & 9.38 \\
\hline $\begin{array}{l}\text { Return on } \mathrm{C} \\
\text { employed }\end{array}$ & 27.18 & 18.53 & 3.98 & 200.91 \\
\hline & $\begin{array}{l}\text { ALI } \\
\text { COMPANE } \\
\text { S(096) }\end{array}$ & & & \\
\hline Saving Ratio & 0.69 & 0.24 & 0 & 1 \\
\hline Dividend \% & 29.73 & 99.64 & 0 & 5750 \\
\hline Interest burden & 0.41 & 0.26 & 0 & 1.00 \\
\hline Tax burc & 0.40 & 1.44 & -0.125 & 125 \\
\hline & 0.99 & 6.82 & -560.5 & 102.65 \\
\hline $\begin{array}{l}\text { Return on } c_{a} \\
\text { employed }\end{array}$ & 26.81 & 29.50 & -148.3 & 1473.2 \\
\hline
\end{tabular}


Table 3

\begin{tabular}{|c|c|c|c|c|}
\hline \multicolumn{5}{|c|}{ Mean values of CEA companies } \\
\hline Year & Saving ratio & Dividend \% & Tax burden & Interest burden \\
\hline 1990 & 0.71 & 23 & 0.27 & 0.39 \\
\hline 1991 & 0.74 & 26 & 0.28 & 0.35 \\
\hline 1992 & 0.71 & 27 & 0.34 & 0.39 \\
\hline 1993 & 0.68 & 27 & 0.20 & 0.43 \\
\hline 1994 & 0.71 & 32 & 0.27 & 0.36 \\
\hline 1995 & 0.74 & 34 & 0.24 & 0.30 \\
\hline 1996 & 0.73 & 37 & 0.22 & 0.32 \\
\hline 1997 & 0.66 & 38 & 0.25 & 0.37 \\
\hline 1998 & 0.67 & 44 & 0.21 & 0.35 \\
\hline 1999 & 0.64 & 42 & 0.21 & 0.37 \\
\hline 2000 & 0.66 & 47 & 0.20 & 0.32 \\
\hline 2001 & 0.63 & 47 & 0.21 & 0.33 \\
\hline 2002 & 0.61 & 50 & 0.28 & 0.33 \\
\hline 2003 & 0.63 & 58 & 0.29 & 0.24 \\
\hline 2004 & 0.61 & 84 & 0.29 & 0.19 \\
\hline Overall & 0.68 & 41 & 0.26 & 0.34 \\
\hline & & & & \\
\hline
\end{tabular}

Table 4

\begin{tabular}{|c|c|c|c|c|}
\hline \multicolumn{5}{|c|}{ Mean values of All companies } \\
\hline Year & Saving ratio & Dividend \% & Interest burden & Tax burden \\
\hline 1990 & 0.70 & 21 & 0.42 & 0.25 \\
\hline 1991 & 0.73 & 21 & 0.41 & 0.24 \\
\hline 1992 & 0.70 & 24 & 0.44 & 0.26 \\
\hline 1993 & 0.68 & 28 & 0.46 & 0.23 \\
\hline 1994 & 0.70 & 25 & 0.38 & 0.21 \\
\hline 1995 & 0.72 & 29 & 0.35 & 0.18 \\
\hline 1996 & 0.72 & 30 & 0.39 & 0.18 \\
\hline 1997 & 0.66 & 30 & 0.44 & 0.22 \\
\hline 1998 & 0.69 & 29 & 0.45 & 0.19 \\
\hline 1999 & 0.66 & 29 & 0.47 & 0.19 \\
\hline 2000 & 0.68 & 30 & 0.44 & 0.18 \\
\hline 2001 & 0.68 & 29 & 0.44 & 0.19 \\
\hline 2002 & 0.69 & 35 & 0.41 & 0.27 \\
\hline 2003 & 0.70 & 40 & 0.36 & 0.28 \\
\hline 2004 & 0.66 & 62 & 0.27 & 0.28 \\
\hline Overall & 0.69 & 30 & 0.41 & 0.22 \\
\hline
\end{tabular}

\begin{tabular}{|c|l|c|c|c|c|c|c|}
\hline \multicolumn{7}{|c|}{ Mean values of CEA companies } \\
\hline & \multicolumn{1}{|c|}{ Industry* } & $\begin{array}{c}\text { Current } \\
\text { ratio }\end{array}$ & $\begin{array}{c}\text { Quick } \\
\text { ratio }\end{array}$ & $\begin{array}{c}\text { Saving } \\
\text { ratio }\end{array}$ & $\begin{array}{c}\text { Interest } \\
\text { burden }\end{array}$ & $\begin{array}{c}\text { Tax } \\
\text { burden }\end{array}$ & $\begin{array}{c}\text { Dividend } \\
\%\end{array}$ \\
\hline 1. & Automobile & 1.73 & 0.74 & 0.64 & 0.28 & 0.25 & 51.52 \\
\hline 2. & Automobile ancillary & 1.59 & 0.75 & 0.63 & 0.34 & 0.26 & 44.08 \\
\hline 3. & Cement & 1.87 & 0.60 & 0.84 & 0.45 & 0.19 & 43.70 \\
\hline 4. & Chemicals & 1.53 & 0.79 & 0.66 & 0.42 & 0.38 & 9.47 \\
\hline 5. & Diversified & 1.59 & 0.65 & 0.71 & 0.39 & 0.23 & 39.79 \\
\hline 6. & Electrical products & 2.12 & 0.76 & 0.65 & 0.31 & 0.22 & 40.10 \\
\hline 7. & Industrial products & 2.12 & 0.88 & 0.66 & 0.29 & 0.33 & 43.17 \\
\hline 8. & Iron and steel & 1.63 & 0.74 & 0.61 & 0.36 & 0.25 & 49.98 \\
\hline 9. & Machine manufacturer & 2.24 & 1.01 & 0.66 & 0.27 & 0.33 & 44.41 \\
\hline 10. & Pharmaceutical & 2.08 & 0.89 & 0.71 & 0.22 & 0.24 & 49.01 \\
\hline 11. & Software & 1.80 & 0.93 & 0.78 & 0.19 & 0.23 & 85.37 \\
\hline 12. & Textile & 1.82 & 0.45 & 0.71 & 0.46 & 0.16 & 29.05 \\
\hline \multicolumn{2}{|l|}{ Over all } & 1.84 & 0.73 & 0.68 & 0.34 & 0.26 & 41.28 \\
\hline
\end{tabular}

* Only 12 industries have been considered in the study. 


\begin{tabular}{|c|c|c|c|c|c|c|c|}
\hline \multicolumn{8}{|c|}{$\begin{array}{c}\text { Table } 6 \\
\text { Mean values of All Companies }\end{array}$} \\
\hline & Industry & $\begin{array}{l}\text { Current } \\
\text { ratio }\end{array}$ & $\begin{array}{l}\text { Saving } \\
\text { ratio }\end{array}$ & $\begin{array}{l}\text { Quick } \\
\text { ratio }\end{array}$ & $\begin{array}{l}\text { Interest } \\
\text { burden }\end{array}$ & $\begin{array}{c}\text { Tax } \\
\text { burden }\end{array}$ & $\begin{array}{c}\text { Dividend } \\
\%\end{array}$ \\
\hline 1. & Automobile & 1.52 & 0.71 & 0.59 & 0.29 & 0.26 & 58.16 \\
\hline 2. & Automobile ancillary & 1.55 & 0.67 & 0.73 & 0.40 & 0.23 & 28.03 \\
\hline 3. & Cement & 1.74 & 0.68 & 0.60 & 0.49 & 0.13 & 29.99 \\
\hline 4. & Chemicals & 1.69 & 0.68 & 0.73 & 0.43 & 0.19 & 22.50 \\
\hline 5. & Diversified & 1.54 & 0.66 & 0.59 & 0.48 & 0.19 & 44.42 \\
\hline 6. & Electrical products & 1.77 & 0.72 & 0.79 & 0.43 & 0.27 & 19.74 \\
\hline 7. & Industrial products & 1.71 & 0.68 & 0.71 & 0.43 & 0.26 & 25.33 \\
\hline 8. & Iron and steel & 1.85 & 0.73 & 0.76 & 0.48 & 0.17 & 17.18 \\
\hline 9. & Machine manufacturer & 1.78 & 0.69 & 0.76 & 0.35 & 0.30 & 31.06 \\
\hline 10. & Pharmaceutical & 1.94 & 0.70 & 0.80 & 0.32 & 0.24 & 35.88 \\
\hline 11. & Software & 4.72 & 0.82 & 2.50 & 0.20 & 0.12 & 59.43 \\
\hline 12. & Textile & 1.78 & 0.72 & 0.54 & 0.52 & 0.14 & 19.03 \\
\hline & Over all & 1.82 & 0.69 & 0.76 & 0.41 & 0.22 & 29.73 \\
\hline
\end{tabular}

Table 7

\begin{tabular}{|c|c|c|c|c|c|c|c|c|c|}
\hline \multicolumn{10}{|c|}{$\begin{array}{l}\text { All companies Regression models } \\
\text { Unstanderdized coefficients }\end{array}$} \\
\hline Industry & $\begin{array}{c}\text { Number } \\
\text { of } \\
\text { Obser- } \\
\text { vations }\end{array}$ & $\begin{array}{l}\text { Divi- } \\
\text { dend }\end{array}$ & $\begin{array}{l}\text { Depreci- } \\
\text { ation }\end{array}$ & Tax & Interest & $\begin{array}{l}\text { Working } \\
\text { Capital }\end{array}$ & $\mathbf{R}$ & $\begin{array}{l}\text { Adj R } \\
\text { Square }\end{array}$ & $\begin{array}{l}\text { Durbin } \\
\text { Waston }\end{array}$ \\
\hline Automobile & 188 & -0.639 & 0.259 & 1.614 & $x$ & 3.53 & 0.951 & 0.902 & 1.257 \\
\hline Automobile ancillary & 655 & 0.466 & 0 & 0.858 & $x$ & 9.639 & 0.966 & 0.933 & 1.335 \\
\hline Cement & 151 & 1.734 & -0.309 & 0.74 & $\bar{x}$ & 0 & 0.759 & 0.567 & 1.601 \\
\hline Chemicals & 1100 & 1 & 0.694 & 0.933 & $x$ & 2.945 & 0.795 & 0.632 & 0.722 \\
\hline Diversified & 384 & 0.389 & 1.971 & -1.02 & -0.917 & 4.218 & 0.974 & 0.947 & 1.349 \\
\hline Electrical products & 639 & $x$ & 0.603 & 0.065 & 0.25 & -3.86 & 0.983 & 0.967 & 1.339 \\
\hline Industrial products & 536 & 0.745 & -0.271 & 0.633 & 0.338 & 2.669 & 0.82 & 0.67 & 0.996 \\
\hline Iron and steel & 709 & 1.631 & -0.482 & 0.927 & 0.339 & -2.78 & 0.976 & 0.952 & 1.662 \\
\hline Machine manufacturer & 693 & -0.609 & 0.48 & 0.8 & -0.16 & 0.118 & 0.926 & 0.856 & 1.323 \\
\hline Pharmaceutical & 819 & 0 & 1.276 & 0.24 & -0.663 & 0.206 & 0.915 & 0.837 & 1.151 \\
\hline Software & 288 & -0.866 & 1.613 & 2.371 & 0.774 & 0.104 & 0.931 & 0.864 & 1.255 \\
\hline Textile & 924 & 0.496 & 0.42 & 0.635 & $x$ & 5.22 & 0.781 & 0.609 & 1.22 \\
\hline Over all (896 firms) & 11055 & -0.106 & 1.032 & 0.833 & -0.187 & 5.112 & 0.918 & 0.842 & 1.072 \\
\hline
\end{tabular}

Only 12 industries are considered

\begin{tabular}{|c|c|c|c|c|c|c|c|c|c|}
\hline \multicolumn{10}{|c|}{$\begin{array}{c}\text { CEA companies Regression models } \\
\text { Unstanderdized coefficients }\end{array}$} \\
\hline Industry & $\begin{array}{c}\text { Number } \\
\text { of } \\
\text { Obser- } \\
\text { vations }\end{array}$ & $\begin{array}{l}\text { Divi- } \\
\text { dend }\end{array}$ & $\begin{array}{l}\text { Depreci- } \\
\text { ation }\end{array}$ & $\operatorname{Tax}$ & Interest & $\begin{array}{l}\text { Working } \\
\text { Capital }\end{array}$ & $\mathbf{R}$ & $\begin{array}{c}\text { Adj R } \\
\text { Square }\end{array}$ & $\begin{array}{l}\text { Durbin } \\
\text { Waston }\end{array}$ \\
\hline Automobile & 60 & $x$ & $x$ & 1.28 & -0.299 & 8.9 & 0.971 & 0.941 & 1.09 \\
\hline Automobile ancillary & 135 & 0.846 & $x$ & 0.692 & $x$ & 5.554 & 0.88 & 0.77 & 1.21 \\
\hline Cement & 30 & 12.15 & -1.45 & $x$ & $x$ & -8.52 & 0.796 & 0.59 & 1.06 \\
\hline Chemicals & 105 & 0.482 & 0.245 & 0.59 & $x$ & $x$ & 0.71 & 0.49 & 1.50 \\
\hline Diversified & 75 & 3.682 & 0.167 & $x$ & $x$ & -7.03 & 0.993 & 0.986 & 1.74 \\
\hline Electrical products & 60 & $x$ & $x$ & 1.123 & $x$ & 7.263 & 0.927 & 0.855 & 1.05 \\
\hline Industrial products & 105 & $x$ & .0 .349 & 0.991 & 0.41 & 0.145 & 0.919 & 0.835 & 1.27 \\
\hline Iron and steel & 45 & 2.99 & -0.802 & 0.614 & $x$ & $x$ & 0.986 & 0.971 & 2.02 \\
\hline Machine manufacturer & 150 & -0.699 & 0.522 & 0.954 & -0.236 & 0.115 & 0.966 & 0.931 & 1.45 \\
\hline Pharmaceutical & 135 & $\mathbf{x}$ & 1.03 & 0.296 & $x$ & 0.225 & 0.944 & 0.889 & 1.53 \\
\hline Software & 30 & -1.1129 & 1.69 & 1.693 & $x$ & 0.263 & 0.995 & 0.989 & 1.93 \\
\hline Textile & 195 & 1.489 & -0.251 & 0.79 & 0.133 & 4.375 & 0.877 & 0.764 & 1.11 \\
\hline Over all (113 firms) & 1695 & 0.606 & 1.21 & 0.464 & -0.504 & 0.737 & 0.956 & 0.913 & 1.27 \\
\hline
\end{tabular}

